\title{
PENGARUH PROFITABILITAS, LEVERAGE DAN UKURAN PERUSAHAAN TERHADAP PENGHINDARAN PAJAK (TAX AVOIDANCE)
}

\author{
Rachmat Sulaeman \\ Universitas Sangga Buana (USB) YPKP Bandung Jawa Barat, Indonesia \\ Email: apex.rahmat@gmail.com
}

\begin{abstract}
This study aims to analyze the effect of profitability, leverage and company size on tax avoidance. The dependent variable in the study was tax avoidance as measured by using the cash effective tax rate (CETR). This study selects the object of research in the form of financial reports from property and real estate sector companies listed on the Indonesia Stock Exchange (BEI) in 2014-2018. The number of research samples of 30 companies obtained by purposive sampling method with data analysis techniques using multiple linear regression analysis. The results of the analysis show that profitability and company size have a significant positive effect on tax avoidance. This shows that the higher the profitability and company size, the higher the tax avoidance, but in this study Leverage has a significant negative effect on tax avoidance. This shows that the higher the leverage, the lower the tax avoidance.
\end{abstract}

Keywords: tax avoidance; profitability; leverage and company size

\begin{abstract}
Abstrak
Penelitian ini bertujuan untuk menganalisis pengaruh profitabilitas, leverage dan ukuran perusahaan terhadap penghindaran pajak (Tax Avoidance). Variabel dependen dalam penelitian berupa pengindaran pajak yang diukur dengan menggunakan cash effective tax rate (CETR). Penelitian ini memilih objek penelitian berupa laporan keuangan dari perusahaan sektor property dan real estate yang terdaftar di Bursa Efek Indonesia (BEI) tahun 2014-2018. Jumlah sampel penelitian sebanyak 30 perusahaan yang diperoleh dengan metode purposive sampling dengan teknik analisis data menggunakan analisis regresi linier berganda. Hasil analisis menunjukkan bahwa profitabilitas, dan ukuran perusahaan berpengaruh positif signifikan terhadap penghindaran pajak. Hal ini menunjukkan bahwa semakin tinggi profitabilitas dan ukuran perusahaan, maka semakin tinggi penghindaran pajak, namun dalam penelitian ini Leverage berpengaruh negatif signifikan terhadap penghindaran pajak. Hal ini menunjukkan bahwa semakin tinggi leverage, maka semakin rendah penghindaran pajak.
\end{abstract}

Kata kunci: profitabilitas; penghindaran pajak; leverage; ukuran perusahaan

\section{Pendahuluan}

Pajak merupakan salah satu sumber penerimaan yang sangat besar yang digunakan untuk melaksakan pembangunan, Pajak dipungut dari warga Negara 
Indonesia dan menjadi salah satu kewajiban yang dapat dipaksakan penagihannya. Pembangunan nasional Indonesia pada dasarnya dilakukan oleh masyarakat bersamasama pemerintah (Wijoyanti, 2010). Oleh karena itu peran masyarakat dalam pembiayaan pembangunan harus terus ditumbuhkan dengan meningkatkan kesadaran masyarakat tentang kewajibannya membayar pajak. Sesuai dengan Undang-Undang Nomor 16 tahun 2009 tentang Ketentuan Umum dan Tata Cara Perpajakan pada Pasal 1 ayat 1 menjelaskan definisi pajak yaitu merupakan kontribusi wajib kepada negara yang terutang oleh orang pribadi atau badan yang bersifat memaksa berdasarkan undangundang, dengan tidak mendapatkan imbalan secara langsung dan digunakan untuk keperluan negara bagi sebesar-besarnya kemakmuran rakyat.

Pajak dapat diartikan sebagai pungutan yang dilakukan oleh negara terhadap warga negaranya, berdasarkan undang-undang yang berlaku di mana atas pungutan tersebut negara tidak memberikan kontraprestasi secara langsung kepada si pembayar pajak. Pada umumnya pendapatan negara merupakan sumber utama belanja negara di samping komponen pembiayaan APBN yang meliputi penerimaan pajak dan bukan pajak (Jotopurnomo \& Mangoting, 2013).

Dominasi pajak sebagai sumber penerimaan merupakan satu hal yang sangat wajar, sumber penerimaan ini mempunyai umur tidak terbatas, terlebih dengan semakin bertambahnya jumlah penduduk yang mengalami peningkatan setiap tahunnya. Pajak memiliki peran yang sangat besar dan semakin diandalkan untuk kepentingan pembangunan dan pengeluaran pemerintah (Hardiningsih \& Yulianawati, 2011).

Berdasarkan Laporan Kinerja Direktorat Jendral Pajak (DJP) tahun 2018, Direktorat Jenderal Pajak telah melaksanakan berbagai program dan kegiatan sebagaimana tertuang dalam Peta Strategis Direktorat Jenderal Pajak Tahun 2018 yang diterjemahkan dalam Kontrak Kinerja Direktur Jenderal Pajak Tahun 2018 yang terdiri dari 24 Indikator Kinerja Utama (IKU). Dalam LAKIN Direktorat Jenderal Pajak ini akan dijabarkan perbandingan antara realisasi pencapaian IKU tahun 2018 dengan Kontrak Kinerja tahun 2018, serta beberapa kinerja lainnya yang telah dicapai oleh Direktorat Jenderal Pajak. Situasi dan kondisi perekonomian yang berfluktuasi dan bergerak cepat, serta tuntutan masyarakat yang sangat dinamis, tugas pengelolaan keuangan negara, khususnya di bidang fiskal merupakan sebuah tantangan. Walaupun demikian dengan dimotivasi dengan visi dan misi yang telah ditetapkan, Direktorat Jenderal Pajak senantiasa berupaya untuk mengatasi segala tantangan tersebut, sehingga tugas yang diemban dapat diselesaikan sesuai dengan harapan.

Pada tahun 2018, pencapaian strategis Direktorat Jenderal Pajak dalam mencapai penerimaan tercermin dalam IKU Persentase realisasi penerimaan pajak yang mencapai Rp1.315,93 triliun atau 92,41\% dari target APBN tahun 2018. Hal ini menjadi sesuatu yang membanggakan. Penerimaan yang cukup tinggi dari tahun sebelumnya didapat dengan tanpa didukung dari hasil Tax Amnesty (Pengampunan Pajak) seperti tahuntahun sebelumnya. Penerimaan tahun 2018 yang didukung dari pertumbuhan double digits PPh Migas dan Non Migas, PPN dan PPnBM, serta PBB dan Pajak Lainnya. Penerimaan pajak ini juga mendukung penerimaan negara pada APBN yang tidak 
mengalami perubahan dalam beberapa tahun terakhir. Hal ini menjadi sebuah prestasi yang cukup membanggakan dengan tidak adanya penyesuaian APBN sehingga target pajak yang ditetapkan pada awal tahun tidak dilakukan penyesuaian.

Realisasi penerimaan pajak adalah jumlah realisasi penerimaan pajak neto terhadap target penerimaan pajak. Penerimaan pajak neto DJP adalah jumlah realisasi penerimaan pajak bruto dikurangi pembayaran Surat Perintah Membayar Kelebihan Pembayaran Pajak (SPMKP), Surat Perintah Membayar Imbalan Bunga (SPMIB), dan Surat Perintah Membayar Pengembalian Pendapatan (SPMPP). Target Penerimaan Pajak adalah target yang telah ditetapkan dalam Anggaran Pendapatan dan Belanja Negara (APBN). Dalam APBN 2018, penerimaan pajak ditetapkan sebesar Rp1.424,00 Triliun.

Tabel 1

Persentase Realisasi Penerimaan Pajak dalam Miliar Rupiah

\begin{tabular}{lccc}
\hline Tahun & 2016 & 2017 & 2018 \\
\hline Target & $1.355,20$ & $1.283,57$ & $1.424,00$ \\
\hline Realisasi & $1.105,73$ & $1.151,03$ & $1.315,51$ \\
\hline Capaian & $81,59 \%$ & $89,67 \%$ & $92,24 \%$ \\
\hline
\end{tabular}

Sumber : Laporan Kinerja 2018 Direktorat Jendral Pajak

Target penerimaan pajak dalam APBN 2018 sebesar Rp1.424,00 triliun, penerimaan pajak sampai dengan Desember 2018 mencapai Rp1.313,51 triliun, yaitu sebesar 92,24\% dari target. Persentase capaian penerimaan pajak tahun 2018 ini lebih baik dibandingkan dengan capaian periode yang sama di tahun 2017, yaitu sebesar 89,67\%. Capaian yang diraih tanpa mekanisme perubahan APBN ini merupakan yang tertinggi dalam lima tahun terakhir.

Dari Tabel 1. serta dari hasil laporan Kinerja DJP 2018 terlihat keseriusan pemerintah dalam meningkatkan pendapatan negara dari sektor pajak. Hal ini sangat wajar karena Pajak merupakan alternatif yang sangat potensial. Sebagai salah satu sumber penerimaan Negara yang sangat potensial, sektor pajak merupakan pilihan yang sangat tepat, selain karena jumlahnya yang relatif stabil juga merupakan cerminan partisipasi aktif masyarakat dalam membiayai pembangunan.

Dalam sistem pemungutan pajak, terdapat 3 (tiga) macam pemungutan pajak yaitu Official Assessment System, Self Assessment System, With Holding System. Official Assessment System adalah system pemungutan pajak yang memberi wewenang pemerintah (fiskus) untuk menentukan besarnya pajak yang terutang oleh Wajib Pajak. Self Assessment System adalah system pemungutan pajak yang memberi wewenang kepada Wajib Pajak untuk menentukan sendiri besarnya pajak yang terutang dan With Holding System adalah system pemungutan pajak yang memberi wewenang kepada pihak ketiga (bukan fiskus atau Wajib Pajak yang bersangkutan) untuk menentukan besarnya pajak yang terutang oleh Wajib Pajak.

Indonesia menganut Self Assessment System, yaitu Wajib Pajak diberi kepercayaan untuk menghitung, memperhitungkan, menetapkan, membayar, dan melaporkan pajaknya sendiri. Fiskus, dalam hal ini aparat Direktorat Jendral Pajak atau Pemerintah Daerah hanya menjalankan fungsi pembinaan, penelitian, pengawasan, dan 
penerapan sanksi administrasi perpajakan (Diamastuti, 2016). Penagihan pajak dalam sistem Self Assessment dilaksanakan sedini mungkin sejak timbulnya hutang pajak atau sebelum tanggal jatuh tempo pembayaran atau penyetoran pajak, penerapan undang undang perpajakan ini memberikan kesempatan pada wajib pajak, dalam hal ini perusahaan untuk mengurangi jumlah pajak yang harus dibayar dengan cara menekan biaya perusahaan, termasuk didalamnya beban pajak, sehingga banyak perusahaan yang berupaya untuk memperkecil pajak dengan legal maupun illegal dan mereka mampu mencapai target laba yang telah ditetapkan (Surya, 2014).

Strategi yang digunakan perusahaan untuk mengurangi atau meminimalkan beban pajak yaitu dengan cara perencanaan pajak atau tax planning. Pada prinsipnya, tax planning (perencanaan pajak) bukan merupakan sesuatu yang keliru atau terlarang. Namun sebuah skema perencanaan pajak harus diuji apakah skema tersebut sesuai atau melanggar Undang-undang.

Tax avoidance dan tax evasion yang membedakannya adalah legalitasnya, tax avoidance bersifat legal, sedangkan tax evasion bersifat ilegal. Dilapangan, pengelompokan antara keduanya tergantung pada interpretasi otoritas pajak di masingmasing negara. Maka disimpulkan bahwa yang membedakan suatu skema perencanaan pajak termasuk kategori tax avoidance atau tax evasion adalah legalitasnya, sedangkan dari sisi etis, kedua praktik ini sebenarnya bertentangan dengan maksud dari undangundang (Fikri, 2017).

Salah satu cara perencanaan pajak (tax planning) yang dilakukan perusahaan untuk mengurangi jumlah pajak yang dibayarkan yaitu dengan cara penghindaran pajak (tax avoidance), dimana cara ini termasuk legal dan lebih aman karena memanfaatkan kelemahan-kelemahan yang terdapat dalam Undang-undang dan Peraturan Perpajakan sehingga tidak bertentangan dengan ketentuan perpajakan yang berlaku dibandingkan dengan tax evasion. Tax avoidance yg terjadi di indonesia disebabkan rendahnya moral pajak pada masyarakat, moral pajak ini yg merupakan penentu kepatuhan wajib pajak dan perilaku lainnya yg dilakukan oleh wajib pajak (Kustiawan, Prawira, Zulhaim, \& Solikin, 2019). Menurut (Cahyono, Andini, \& Raharjo, 2016) penghindaran pajak bertujuan meminimalkan beban pajak dengan memanfaatkan celah (loophole) ketentuan perpajakan suatu negara.

Penelitian yang dilakukan oleh (Suryani \& Mariani, 2019) dengan menggunakan Variabel Umur Perusahaan, Ukuran Perusahaan dan Profitabilitas. Hasil penelitian menunjukan bahwa Umur Perusahaan berpengaruh positif terhadap tax avoidance, dan profitabilitas berpengaruh negatif terhadap Penghindaran Pajak Sedangkan Ukuran Perusahaan tidak berpengaruh terhadap tax avoidance.

Penelitian ini merupakan pengembangan dari penelitian sebelumnya yaitu penelitian (Surbakti, 2012) yang berjudul Pengaruh KarakteristikPerusahaan dan reformasi Perpajakan terhadap Penghindaran Pajak di Perusahaan Industri Manufaktur yang Terdaftar di Bursa Efek Indonesia. Perbedaan penelitian ini dengan penelitian (Surbakti, 2012) terletak pada variabel, sampel dan tahun penelitian, yaitu penelitian ini menggunakan variabel independen Profitabilitas 
(ROA), Size, Leverage, Capital Intensity, dan Inventory Intensityserta menggunakan ETR sebagai proksi untuk mengukur penghindaran pajak perusahaan. Sampel perusahaan yang digunakan merupakan perusahaan manufaktur yang terdaftar di BEI tahun 2010-2014.

Penelitian yang dilakukan oleh (Jamaludin, 2020) dengan menggunakan Variabel Profitabilitas, Leverage, dan Intensitas Aktiva Tetap. Hasil penelitian menunjukan bahwa Profitabilitas, Leverage, dan Intensitas Aktiva Tetap tidak berpengaruh terhadap tax avoidance.

Berdasarkan latar belakang dan penjabaran hasil penelitian di atas, diketahui masih adanya perbedaan hasil penelitian (research gap) pada penelitian terdahulu. Hal ini menjadi dasar bagi penulis untuk melakukan penelitian ulang tentang tax avoidance. Sehingga, hasil dari penelitian ini dapat mengkonfirmasi atas penelitian terdahulu maupun sebagai masukkan terkait tax avoidance. Sebagai objek penelitian, penulis fokus kepada perusahaan property yang terdaftar di bursa efek Indonesia tahun 20142018. Pemilihan objek ini sebagai pembeda dan berdasarkan latar belakang yang dijabarkan di atas. Penelitian ini bertujuan untuk menganalisis pengaruh profitabilitas, leverage dan ukuran perusahaan terhadap penghindaran pajak (Tax Avoidance).

\section{Metode Penelitian}

Metode yang digunakan penelitian pada dasarnya untuk menunjukkan kebenaran dan pemecahan masalah atau apa yang diteliti. Untuk mencapai tujuan tersebut, dilakukan suatu metode yang tepat dan relevan untuk tujuan yang diteliti. Dalam melakukan penelitian ini penulis menggunakan pendekatan penelitian kuantitatif dengan metode deskriptif dan verifikatif. Menurut (Sugiyono, 2010), metode kuantitatif adalah

"Metode penelitian yang berdasarkan pada filsafat positivisme, digunakan untuk meneliti pada populasi suatu sampel tertentu, teknik pengambilan sampel pada umumnya random, pengumpulan data menggunakan instrumen penelitian, analisis data bersifat kuantitatif atau statistik dengan tujuan untuk menguji hipotesis yang telah ditetapkan".

Dalam penelitian ini analisis deskriftif dan verifikatif digunakan untuk mengetahui pengaruh Profitabilitas, Laverage dan Ukuruan Perusahaan terhadap Tax Avoidance pada perusahaan property dan real estate yang terdaftar di Bursa Efek Indonesia pada tahun 2014-2018.

\section{Hasil dan Pembahasan}

\section{Hasil Uji Analisis Data}

Perusahaan Property dan Real Estate yang terdaftar di Bursa Efek Indonesia (BEI) pada tahun 2014-2018 yang dijadikan Populasi oleh peneliti, Adapun Jumlah perusahaan property dan real estate yang terdaftar di BEI tahun 2018 sebanyak 48 perusahaan. Pemilihan sampel dipilih dengan menggunakan metode purposive sampling. Dengan melakukan seleksi pemilihan sampel berdasarkan kriteria yang telah ditentukan, maka diperoleh sampel sebanyak 30 perusahaan yang memenuhi 
kriteria. Berikut Hasi seleksi dalam pengambilan sampel Perusahaan property dan real estate untuk penelitian ini:

Tabel 1

Proses Seleksi Sampel Penelitian

\begin{tabular}{rlc}
\hline No & \multicolumn{1}{c}{ Kriteria } & Jumlah \\
\hline 1. & $\begin{array}{l}\text { Perusahaan sektor property dan real estate yang terdaftar di } \\
\text { Bursa Efek Indonesia tahun 2014-2018 }\end{array}$ & 48 \\
\hline 2. & $\begin{array}{l}\text { Perusahaan sektor property dan real estate yang tidak } \\
\text { mempublikasikan laporan keuangan untuk tahun 2014- }\end{array}$ & $(19)$ \\
& \\
\hline 2018 & $\begin{array}{l}\text { Perusahaan sektor property dan real estate yang } \\
\text { mengalami rugi selama periode 2014-2018. }\end{array}$ & $(10)$ \\
\hline 4. & $\begin{array}{l}\text { Perusahaan sektor property dan real estate yang tidak } \\
\text { mempublikasikan annual report untuk tahun 2014-2018. }\end{array}$ & $(1)$ \\
\hline 5. & Perusahaan yang memenuhi kriteria & 30 \\
\hline 6. & $\begin{array}{l}\text { Jumlah sampel perusahaan selama tahun 2014-2018 (30 } \\
\text { perusahaan x 5 tahun) }\end{array}$ & 150 \\
\hline 7. & Data Outlier Sumber : Data diolah 2020 & $\mathbf{1 3 1}$ \\
\hline & Jumlah sampel yang digunakan dalam penelitian \\
\hline
\end{tabular}

Data dari 30 sampel perusahaan tersebut dapat dilihat pada lampiran 1 . Sehingga Jumlah sampel perusahaan Property dan Real Estate terdaftar BEI dari 2014 -2018 yang digunakan dalam penelitian ini sebanyak 131 perusahaan.

\section{Analisis Statistik Deskriptif}

Menurut Menurut (Ghozali, 2016) analisis statistik deskriptif memberikan gambaran atau deskripsi pada suatu data yang dapat diukur dengan nilai ratarata (mean), minimum, maksimum serta standar deviasi yang terdapat dalam penelitian.

Tabel 2

Hasil Perhitungan Statistik Deskriptif Setelah Penghapusan Outlier

\begin{tabular}{lrrrrr}
\hline \multicolumn{7}{c}{ Descriptive Statistics } \\
\hline & $\mathrm{N}$ & Minimum & Maximum & \multicolumn{1}{c}{ Mean } & Std. Deviation \\
\hline ROA & 131 & 1.00 & 286.00 & 60.2748 & 56.10595 \\
\hline DER & 131 & 5.00 & 3094.00 & 705.3282 & 536.40918 \\
\hline LnTR & 131 & 2806.00 & 31584.00 & 27629.4580 & 6836.43421 \\
\hline CETR & 131 & .00 & 1767.00 & 283.2748 & 270.27536 \\
\hline Valid N (listwise) & 131 & & & & \\
\hline \multicolumn{5}{c}{ Sumber : Data diolah 2020 }
\end{tabular}

Dari hasil perhitungan statistik deskriptif menggunakan SPSS diperoleh data tersajikan pada tabel 2, serta dapat dianalisa sebagai berikut:

1. Profitabilitas

Hasil statistik deskriptif dari perusahaan properti selama 5 tahun yang terdaftar di Bursa Efek Indonesia (BEI) tahun 2014-2018 menunjukkan nilai maksimum Profitabilitas sebesar 286,00 terjadi pada Danayasa Arthatama Tbk (SCMD) pada tahun 2015. Sedangkan, nilai minimumnya sebesar 1,00 terjadi 
pada Gading Development Tbk (GAMA) pada tahun 2018. Profitabilitas memiliki nilai rata-rata (mean) sebesar 60,2748 dan standar deviasi sebesar 56,10595. Nilai rata-rata tersebut menunjukkan bahwa sebagian besar perusahaan sampel memiliki tingkat profit yang tinggi karena mendekati nilai maksimum. Nilai standar deviasi yang lebih rendah daripada nilai rata- rata menunjukkan bahwa data relatif homogen.

2. Leverage

Hasil statistik deskriptif dari perusahaan properti selama 5 tahun yang terdaftar di Bursa Efek Indonesia (BEI) tahun 2014-2018 menunjukkan nilai maksimum leverage sebesar 3,094.00 terjadi pada Plaza Indonesia Reality.Tbk (PLIN) pada tahun 2018. Sedangkan, nilai minimum leverage sebesar 5.00 terjadi pada Metropolitan Kentjana Tbk (MKPI) pada tahun 2017. Nilai rata-rata (mean) leverage sebesar 705.3282 dan standar deviasi sebesar 536.40918. Nilai rata-rata tersebut menunjukkan bahwa sebagian besar perusahaan sampel memiliki leverage yang rendah karena mendekati nilai minimum. Nilai standar deviasi yang lebih rendah daripada nilai rata-rata menunjukkan bahwa data relatif homogen.

3. Ukuran Perusahaan

Hasil statistik deskriptif dari perusahaan properti selama 5 tahun yang terdaftar di Bursa Efek Indonesia (BEI) tahun 2014 - 2018 menunjukkan nilai maksimum ukuran perusahaan sebesar 31584.00 terjadi pada Bumi Serpong Damai Tbk (BSDE) pada tahun 2017. Sedangkan, nilai minimum ukuran perusahaan sebesar 2806.00 terjadi pada Perdana Gapura Prima Tbk (GPRA) pada tahun 2018. Nilai rata-rata (mean) ukuran perusahaan sebesar 27629.4580 dan standar deviasi sebesar 6836.43421. Nilai rata-rata tersebut menunjukkan bahwa sebagian besar perusahaan sampel memiliki ukuran perusahaan yang tinggi karena mendekati nilai maksimum. Nilai standar deviasi yang lebih rendah daripada nilai rata-rata menunjukkan bahwa data relatif homogen.

\section{Uji Koefisien Determinasi (R2)}

Koefisien determinasi $\left(\mathrm{R}^{2}\right)$ pada intinya mengukur seberapa jauh kemampuan model dalam menerangkan variasi variabel dependen. Nilai koefisien determinasi adalah antara nol dan satu. Nilai $\mathrm{R}^{2}$ yang kecil berarti kemampuan variabelvariabel independen dalam menjelaskan variasi variabel-variabel dependen amat terbatas. Nilai yang mendekati satu berarti variabel-variabel independen memberikan hampir semua informasi yang dibutuhkan untuk memprediksi variasi variable dependen. Hasil perhitungan uji koefisien determinasi dapat dilihat dalam tabel 2 berdasarkan tabel 2 diperoleh koefisien regresi Adjusted $R$ Square sebesar 0,161 yang menunjukan bahwa kemampuan variabel profitabilitas, leverage, dan ukuran perusahaan dalam menjelaskan variasi variabel penghindaran pajak sebesar $16,1 \%$ dan sisanya yaitu sebesar $83,9 \%$ dijelaskan oleh variabel-variabel lain diluar persamaan. Dengan nilai koefisien Adjusted $R$ Square yamg hanya sebesar 0,161 
maka kemampuan variabel dependennya relatif tinggi maka kemampuan variabel independen yang baik dalam menjelaskan variasi variabel dependennya apabila memiliki nilai Adjusted $R$ Square yang mendekati nilai 1 .

\section{Uji Asumsi Klasik}

Uji asumsi klasik adalah pengujian yang biasa digunakan untuk menguji kelayakan model regresi. Uji asumsi klasik yang akan digunakan dalam penelitian ini berupa uji normalitas, uji multikolinearitas, uji heteroskedastisitas, dan uji autokorelasi.

\section{Uji Normalitas}

Uji normalitas bertujuan untuk menguji apakah data dalam penelitian berdistribusi normal atau tidak. Uji yang digunakan dalam penelitian ini adalah uji statistik dengan Kolmogorov-Smirnov. Dasar pengambilan keputusan dengan menggunakan Uji Kolmogorov-Smirnov (1-Sample K-S) adalah apabila nilai Asymp. Sig. (2-tailed) lebih besar dari 0,05 maka data berdistribusi secara normal. Hasil uji normalitas dapat dilihat pada Tabel 3.

\section{Tabel 3}

Uji Normalitas (Sebelum Penghapusan Outlier) One-Sample Kolmogorov-Smirnov Test

\begin{tabular}{|c|c|c|}
\hline & & $\begin{array}{c}\text { Unstandardized } \\
\text { Residual }\end{array}$ \\
\hline $\mathrm{N}$ & & 150 \\
\hline \multirow{2}{*}{ Normal Parameters ${ }^{\mathrm{a}, \mathrm{b}}$} & Mean &, 0000000 \\
\hline & Std. Deviation & ,46253387 \\
\hline Extreme & Absolute & ,199 \\
\hline \multirow[t]{2}{*}{ Differences } & Positive &, 199 \\
\hline & Negative &,- 145 \\
\hline Test Statistic & & ,199 \\
\hline Asymp. Sig. (2-tailed) & &, $000^{\mathrm{c}}$ \\
\hline
\end{tabular}

Sumber : Data diolah 2020

Dari hasil uji normalitas pada tabel 3 diketahui bahwa hasil Asymp. Sig. (2tailed) 0,000 lebih kecil dari 0,05 yang menunjukan bahwa data berdistribusi tidak normal sehingga dilakukan penghapusan data outlier. Data outlier adalah data yang memiliki karakteristik unik yang terlihat sangat berbeda jauh dari observasi dan muncul dalam bentuk nilai yang ekstrim (Ghozali, 2018). Setelah didapat hasil bahwa terdapat data berdistribusi tidak normal maka dilakukan uji outlier, uji outlier dilakukan dengan melihat grafik box plot, angka-angka yang terletak diluar boxplot merupakan angka observasi yang perlu dihilangkan. Uji outlier dapat dilihat pada lampiran 6. Hasil uji normalitas setelah penghapusan outlier dapat dilihat pada Tabel 4. 
Tabel 4

Uji Normalitas (Setelah Penghapusan Outlier)

One-Sample Kolmogorov-Smirnov Test

\begin{tabular}{llr}
\hline & & $\begin{array}{r}\text { Unstandardized } \\
\text { Residual }\end{array}$ \\
\hline $\mathrm{N}$ & & 131 \\
\hline Normal Parameters & Mean & .0000000 \\
\cline { 2 - 3 } & Std. Deviation & 244.68126439 \\
\hline Most Extreme Differences & Absolute & .150 \\
\cline { 2 - 3 } & Positive & .150 \\
\cline { 2 - 3 } & Negative & -.105 \\
\hline Test Statistic & & .150 \\
\hline Asymp. Sig. (2-tailed) & & $.000^{c}$ \\
\hline a. Test distribution is Normal. & \\
\hline b. Calculated from data. & & \\
\hline c. Lilliefors Significance Correction. & &
\end{tabular}

Sumber : Data diolah 2020

Dari hasil pengujian One Sample Kolmogorov-Smirnov setelah dilakukan penghapusan outlier dan dilakukan transformasi diperoleh nilai Asymp. Sig (2Tailed) sebesar 0,2 dimana nilai tersebut lebih besar dari tingkat signifikansi yaitu sebesar 0,05. Hasil pengujian ini menunjukan bahwa data dalam penelitian berdistribusi secara normal.

\section{Uji Multikolinearitas}

Uji multikolinearitas bertujuan untuk menguji apakah dalam model regresi ditemukan adanya korelasi antar variabel independen (Janie, 2012). Model regresi dikatakan baik jika tidak terjadi korelasi diantara variabel independen. Ada atau tidaknya multikolinearitas dapat dilihat dari nilai tolerance dan variance inflation factor (VIF). Jika nilai tolerance > 0,10 dan nilai VIF $<10$ maka dikatakan tidak terjadi multikolinearitas. Hasil uji multikolinearitas dapat dilihat pada Tabel 5.

Tabel 5

Hasil Uji Multikolinearitas

\begin{tabular}{|c|c|c|c|c|c|c|c|c|}
\hline \multicolumn{9}{|c|}{ Coefficients $^{\mathrm{a}}$} \\
\hline & & \multicolumn{2}{|c|}{$\begin{array}{c}\text { Unstandardized } \\
\text { Coefficients }\end{array}$} & \multirow{2}{*}{$\begin{array}{c}\text { Standardized } \\
\text { Coefficients } \\
\text { Beta }\end{array}$} & \multirow[b]{2}{*}{$\mathrm{t}$} & \multirow[b]{2}{*}{ Sig. } & \multicolumn{2}{|c|}{$\begin{array}{c}\text { Collinearity } \\
\text { Statistics }\end{array}$} \\
\hline \multicolumn{2}{|c|}{ Model } & B & Std. Error & & & & $\begin{array}{c}\text { Toleranc } \\
\mathrm{e}\end{array}$ & VIF \\
\hline \multirow[t]{4}{*}{1} & (Constant) & 298.113 & 97.621 & & 3.054 & .003 & & \\
\hline & $\mathrm{ROA}$ & -1.787 & .399 & -.371 & -4.475 & .000 & .940 & 1.064 \\
\hline & DER & .071 & .042 & .142 & 1.717 & .088 & .948 & 1.055 \\
\hline & LnTR & .002 & .003 & .039 & .482 & .631 & .991 & 1.009 \\
\hline
\end{tabular}

a. Dependent Variable: CETR

Sumber : Data diolah 2020

Pada tabel 5 hasil pengujian uji multikolinearitas diatas diperoleh nilai tolerance semua variabel independen $>0,10$ dan nilai Variance Inflation Factor 
(VIF) $<10$ sehingga dapat disimpulkan bahwa tidak terjadi multikolinearitas pada model regresi.

\section{Uji Heteroskedastisitas}

Uji heteroskedastisitas bertujuan untuk menguji apakah dalam model regresi terjadi ketidaksamaan variance dari residual suatu pengamatan ke pengamatan yang lain. Jika variance dari residual satu pengamatan ke pengamatan lain tetap, maka disebut homoskedastisitas dan jika berbeda disebut heteroskedastisitas. Model regresi yang baik adalah yang homoskedastisitas atau tidak terjadi heteroskedastisitas (Pamungkas, Ghozali, \& Achmad, 2018). Metode yang digunakan untuk mendeteksi ada atau tidaknya heteroskedastisitas melalui pengujian dengan menggunakan Scatter Plot. Hasil uji heteroskedastisitas dapat dilihat pada gambar 1 .

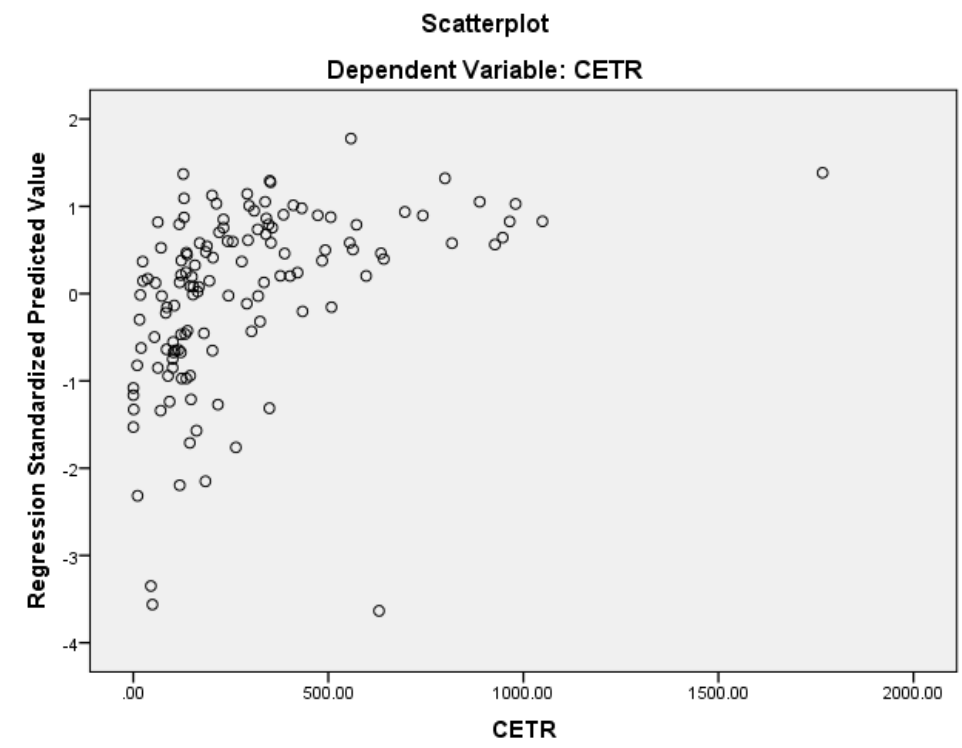

Gambar 1

Uji Heteroskedastisitas

Sumber: Data diolah 2020

Berdasarkan grafik Scatter Plot diatas menunjukkan pola yang tidak jelas, serta titik-titik menyebar di atas dan di bawah angka 0 pada sumbu Y. Jika terjadi heteroskedastisitas grafiknya akan menunjukkan titik-titik yang membentuk pola tertentu secara teratur seperti bergelombang, menyebar kemudian menyempit. Dapat disimpulkan bahwa tidak terjadi heteroskedastisitas pada model regresi karena grafik scatter plot menunjukkan pola yang tidak jelas atau tidak teratur.

\section{Uji Autokorelasi}

Uji autokorelasi bertujuan untuk menguji apakah dalam model regresi linear ada korelasi antara kesalahan pengganggu pada periode $t$ dengan kesalahan pengganggu pada periode t-1 (sebelumnya). Untuk mendeteksi ada tidaknya autokorelasi dengan cara melakukan uji Durbin-Watson (DW test) (Pamungkas et al., 2018). Dikatakan tidak terdapat autokorelasi jika nilai DW > DU dan (4- DU) > 
DW atau bisa dinotasikan dengan DU < DW < (4-DU). Hasil uji autokorelasi dapat dilihat pada Tabel 6 .

\begin{tabular}{|c|c|c|c|c|c|c|c|c|c|c|}
\hline \multirow[b]{3}{*}{ Model } & \multirow[b]{3}{*}{$\mathrm{R}$} & \multirow[b]{3}{*}{$\begin{array}{c}\mathrm{R} \\
\text { Square }\end{array}$} & \multicolumn{4}{|c|}{$\begin{array}{c}\text { Tabel } 6 \\
\text { Uji Autokorelasi } \\
\text { Model Summary }\end{array}$} & & & & \multirow[b]{3}{*}{$\begin{array}{l}\text { Durbin } \\
\text { Watson }\end{array}$} \\
\hline & & & \multirow[b]{2}{*}{$\begin{array}{l}\text { Adjuste } \\
\text { d R } \\
\text { Square }\end{array}$} & \multirow{2}{*}{$\begin{array}{c}\text { Std. } \\
\text { Error of } \\
\text { the } \\
\text { Estimate }\end{array}$} & \multicolumn{5}{|c|}{ Change Statistics } & \\
\hline & & & & & $\begin{array}{c}\mathrm{R} \\
\text { Square } \\
\text { Change }\end{array}$ & $\begin{array}{c}\mathrm{F} \\
\text { Chang } \\
\mathrm{e}\end{array}$ & $\mathrm{df} 1$ & df2 & $\begin{array}{c}\text { Sig. F } \\
\text { Change }\end{array}$ & \\
\hline 1 & $.425^{\mathrm{a}}$ & .180 & .161 & $\begin{array}{r}247.554 \\
33\end{array}$ & .180 & 9.319 & 3 & 127 & .000 & 1.520 \\
\hline & s. & ant & TR, D & ER, ROA & & & & & & \\
\hline
\end{tabular}

Uji autokorelasi diperoleh nilai Durbin Watson (DW) sebesar 1.520. Untuk memperoleh nilai DU dapat dilihat pada tabel Durbin Watson, dimana jumlah sampel (n) yaitu 131 dan jumlah variabel (k) yaitu 4 maka diperoleh nilai DU sebesar 0,483 dan dL sebesar 0,663. Jadi dari hasil analisis yang telah dilakukan diperoleh nilai DW 1.520 lebih besar dari batas atas (du) 0,483 dan kurang dari 4du (4-483) atau dapat dinotasikan dengan $0,483<1.520<(41,483)$, maka dapat disimpulkan bahwa tidak terdapat autokorelasi dalam penelitian ini.

1) Analisis Regresi Linear Berganda

Analisis regresi linear berganda digunakan untuk mengetahui arah dan seberapa besar pengaruh variabel independen terhadap variabel dependen. Hasil dari analisis regresi linear berganda akan menguji seberapa besar pengaruh Profitabilitas, leverage, dan ukuran perusahaan terhadap penghindaran pajak

Hasil perhitungan kaoefisien model regresi linear berganda dapat dilihat dalam Tabel 6. Berdasarkan tabel 6 maka diperoleh persamaan regresi linear berganda sebagai berikut:

CETR = 298,113 - 1,787 ROA + 0,71 DER + 0,002 LnTA

Interpretasi dari persamaan regresi linear berganda diatas sebagai berikut:

1. Penghindaran pajak diproksikan menggunakan nilai CETR. Dimana CETR memiliki hubungan berbanding terbalik (negatif) dengan penghindaran pajak, jika terjadi peningkatan nilai CETR menggambarkan penurunan penghindaran pajak. Berdasarkan hasil pengujian hipotesis menunjukkan nilai konstanta CETR sebesar 298,113. Koefisien positif mengandung arti bahwa pengaruh variabel lain yang tidak dijelaskan dalam model regresi memiliki hubungan berbanding lurus dengan CETR. Dengan kata lain variabel lain tersebut memiliki hubungan negatif terhadap penghindaran pajak, mengingat CETR dan penghindaran pajak memiliki hubungan negatif. Oleh karena itu nilai konstanta sebesar 298,113 memiliki makna apabila variabel profitabilitas (ROA), leverage (DER), dan ukuran perusahaan (LnTA) adalah nol maka terjadi penghindaran pajak senilai $298,113$. 
2. Profitabilitas memiliki koefisien regresi sebesar -1,787. Nilai koefisien regresi negatif menunjukkan bahwa profitabilitas memiliki pengaruh negatif terhadap CETR. Berdasarkan teori, semakin rendah nilai CETR maka semakin tinggi penghindaran pajak sehingga nilai koefisien regresi negatif dari profitabilitas menunjukkan bahwa profitabilitas memiliki pengaruh positif terhadap penghindaran pajak. Angka koefisien regresi -1,787 menunjukkan bahwa apabila profitabilitas meningkat sebesar satu persen, maka terjadi penurunan pada CETR sebesar 1,787 persen atau terjadi peningkatan penghindaran pajak sebesar 1,787 persen dengan asumsi variabel independen lainnya konstan.

3. Leverage memiliki koefisien regresi sebesar 0,71. Nilai koefisien regresi positif menunjukkan bahwa leverage memiliki pengaruh positif terhadap CETR. Berdasarkan teori bahwa semakin tinggi nilai CETR maka penghindaran pajaknya semakin rendah, sehingga nilai koefisien regresi positif dari leverage menunjukkan bahwa leverage memiliki pengaruh negatif terhadap penghindaran pajak. Angka koefisien regresi 0,71 menunjukkan bahwa apabila leverage meningkat sebesar satu persen, maka terjadi peningkatan nilai CETR sebesar 0,71 persen atau terjadi penurunan penghindaran pajak sebesar 0,71 persen dengan asumsi variabel independen lainnya konstan.

4. Ukuran perusahaan mempunyai koefisien regresi sebesar -0,002. Nilai koefisien regresi negatif menunjukkan bahwa ukuran perusahaan memiliki pengaruh negatif terhadap CETR. Berdasarkan teori bahwa semakin rendah nilai CETR maka penghindaran pajaknya semakin tinggi, sehingga nilai koefisien regresi negatif dari ukuran perusahaan menunjukkan bahwa ukuran perusahaan memiliki pengaruh positif terhadap penghindaran pajak. Angka koefisien regresi -0,002 menunjukkan bahwa apabila ukuran perusahaan meningkat sebesar satu rupiah, maka terjadi penurunan nilai CETR sebesar 0,002 rupiah atau terjadi peningkatan penghindaran pajak sebesar 0,002 rupiah.

\section{Kesimpulan}

Berdasarkan hasil penelitian yang telah dilakukan sesuai tahapan-tahapan penelitian yang semestinya penulis beranggapan masih banyak kekurangan dari penelitian ini yang berjudul Pengaruh Profitabilitas, leverage, dan ukuran perusahaan terhadap penghindaran pajak, dengan mengambil objek penelitian berupa perusahaan property dan real estate yang terdaftar di BEI dari tahun 2014 sampai dengan 2018, maka penulis menyimpulkan dari penelitian tersebut sebagai berikut: (1) Berdasarkan hasil analisis data diperoleh bahwa Profitabilitas memiliki pengaruh positif signifikan terhadap penghindaran pajak. Artinya semakin tinggi profitabilitas perusahaan maka semakin tinggi tingkat penghindaran pajak yang dilakukan oleh perusahaan. Demikian pula dengan hasil penelitian hipotesis bahwa profitabilitas 
berpengaruh positif terhadap penghindaran pajak diterima. (2) Berdasarkan hasil analisis data diperoleh bahwa leverage memiliki pengaruh negatif terhadap penghindaran pajak. Artinya semakin tinggi leverage maka semakin rendah tingkat penghindaran pajaknya. Demikian pula dengan hasil penelitian hipotesis bahwa leverage berpengaruh positif terhadap penghindaran pajak ditolak. (3) Berdasarkan hasil analisis data diperoleh bahwa ukuran perusahaan memiliki pengaruh positif signifikan terhadap penghindaran pajak. Artinya semakin tinggi ukuran perusahaan maka semakin tinggitingkat penghindaran pajak yang dilakukan oleh perusahaan. Demikian pula dengan hasil penelitian hipotesis bahwa ukuran perusahaan berpengaruh positif terhadap penghindaran pajak diterima.

Hasil uji hipotesis terdapat satu variabel independen yang ditolak yaitu leverage. Pengukuran leverage menggunakan proksi DER dan hasil penelitian menunjukkan leverage berpengaruh negatif terhadap penghindaran pajak sedangkan menurut teori leverage berpengaruh positif terhadap penghindaran pajak.

\section{BIBLIOGRAFI}

Cahyono, Deddy Dyas, Andini, Rita, \& Raharjo, Kharis. (2016). Pengaruh komite audit, kepemilikan institusional, dewan komisaris, ukuran perusahaan (Size), leverage (DER) dan profitabilitas (ROA) terhadap tindakan penghindaran pajak (tax avoidance) pada perusahaan perbankan yang listing BEI periode tahun 2011-2013. Journal Of Accounting, 2(2).

Diamastuti, Erlina. (2016). Ke(tidak) patuhan wajib pajak: potret self assessment system. Ekuitas (Jurnal Ekonomi Dan Keuangan), 20(3), 280-304.

Fikri, Darin Rausan. (2017). Persepsi Mahasiswa Perpajakan Mengenai Penghindaran Pajak (Studi pada Mahasiswa Perpajakan Fakultas Ilmu Administrasi Universitas Brawijaya). Universitas Brawijaya.

Ghozali, Imam. (2016). Aplikasi Analisis Multivariate Dengan Program SPSS. Universitas Diponegoro.

Hardiningsih, Pancawati, \& Yulianawati, Nila. (2011). Faktor-faktor yang mempengaruhi kemauan membayar pajak. Dinamika Keuangan Dan Perbankan, $3(1), 126-142$.

Jamaludin, Ali. (2020). Pengaruh Profitabilitas (Roa), Leverage (Ltder) Dan Intensitas Aktiva Tetap Terhadap Penghindaran Pajak (Tax Avoidance) Pada Perusahaan Subsektor Makanan Dan Minuman Yang Terdaftar Di Bei Periode 2015-2017. Eqien: Jurnal Ekonomi Dan Bisnis, 7(1), 85-92.

Janie, Dyah Nirmala Arum. (2012). Statistik deskriptif \& regresi linier berganda dengan SPSS. Jurnal, April.

Jotopurnomo, Cindy, \& Mangoting, Yenni. (2013). Pengaruh kesadaran wajib pajak, 
kualitas pelayanan fiskus, sanksi perpajakan, lingkungan wajib pajak berada terhadap kepatuhan wajib pajak orang pribadi di Surabaya. Tax \& Accounting Review, 1(1), 49.

Kustiawan, Memen, Prawira, Ida Farida Adi, Zulhaim, Hanifa, \& Solikin, Ikin. (2019). Tax knowledge, Tax Morale, and Tax Compliance: Taxpayers' View. The International Journal of Business Management and Technology, 3(1).

Pamungkas, Imang Dapit, Ghozali, Imam, \& Achmad, Tarmizi. (2018). A pilot study of corporate governance and accounting fraud: The fraud diamond model. Journal of Business and Retail Management Research, 12(2).

Sugiyono. (2010). Metode Penelitian Kuantitatif Kualitatif dan $R$ \& D. Bandung: Alfabeta.

Surbakti, Theresa Adelina Victoria. (2012). Pengaruh karakteristik perusahaan dan reformasi perpajakan terhadap penghindaran pajak di perusahaan industri manufaktur yang terdaftar di bursa efek indonesia tahun 2008-2010. Skripsi Jurnal Akuntansi Fakultas Ekonomi Universitas Indonesia, Jakarta.

Surya, David Marta. (2014). Pengaruh kepemilikan NPWP, sistem self assessment, dan peraturan pemerintah nomor 46 terhadap kepatuhan wajib pajak Usaha Mikro di Galaxy Mall Surabaya dalam membayar pajak. Universitas Katolik Darma Cendika Fakultas Ekonomi.

Suryani, Suryani, \& Mariani, Desy. (2019). Pengaruh Umur Perusahaan, Ukuran Perusahaan Dan Profitabilitas Terhadap Penghindaran Pajak Dengan Leverage Sebagai Variabel Pemoderasi. Jurnal Ilmiah MEA (Manajemen, Ekonomi, \& Akuntansi), 3(3), Press-Press.

Wijoyanti, Mayang. (2010). Pengaruh penagihan pajak dengan surat paksa terhadap kepatuhan wajib pajak di Kantor Pelayanan Pajak Pratama Jakarta Mampang Prapatan. Skripsi. Jakarta: Program Skripsi Fakultas Ekonomi Universitas Pembangunan Nasional "Veteran." 